\title{
Linkage studies in Duchenne and Becker muscular dystrophies
}

\author{
ALISON WALKER*, KEVIN HART*, CHARLOTTE COLE*, \\ SHIRLEY HODGSON*, LYNN JOHNSON*, VICTOR DUBOWITZ†,AND \\ MARTIN BOBROW* \\ From *the Paediatric Research Unit, United Medical and Dental Schools of Guy's and St Thomas's Hospitals, \\ Guy's Tower, London SE1 9RT; and †Department of Paediatrics and Neonatal Medicine, Hammersmith \\ Hospital, Ducane Road, London W12 OHS.
}

SUMMARY We have studied the inheritance of four cloned DNA sequences which recognise restriction fragment length polymorphisms on the short arm of the $\mathrm{X}$ chromosome in families with Becker and Duchenne muscular dystrophy. We have confirmed linkage of two probe loci to the disease loci and have combined our results with those previously published to give a maximum lod score of 11.642 at a recombination fraction of 0.15 for $D X S 41$ (probe 99.6 ), and a maximum lod of 15.84 at a recombination fraction of 0.15 for $D X S 84$ (probe 754). Linkage of these diseases to the loci defined by the pERT87 probes and probe pXJ1.1 has also been studied, giving maximum lod scores of 8.634 and 5.118 at recombination fractions of 0.02 and 0.00 respectively. The information obtained using these polymorphic DNA markers, combined with pedigree and CK data, can be used to give more accurate genetic counselling to women at risk in Becker and Duchenne families.

Duchenne muscular dystrophy (DMD) and Becker muscular dystrophy (BMD) are $\mathrm{X}$ linked recessive muscle disorders. DMD is more common and more severe than BMD, with an incidence of approximately 1 in 3000 to $3500^{1}$ newborn males, compared to approximately 1 in 30000 for BMD. They are clinically similar in the pattern of muscle involvement, but BMD follows a more benign course.

The localisation of DMD on the $\mathrm{X}$ chromosome initially came from the study of several girls who manifested the clinical signs of muscular dystrophy and who were all found to have $X$;autosome translocations, with a common breakpoint at Xp21. ${ }^{2}$ Further evidence came from the linkage of DMD to polymorphic loci defined by cloned DNA sequences, $\mathrm{RC}^{4}$ and $\mathrm{L} 1 \cdot 28 .^{5}$ Since then, other DNA probes have been isolated from this region and have been studied in kindreds showing a family history of DMD and BMD ${ }^{6-10}$ BMD was originally thought to be linked to colour blindness on the terminal portion of $\mathrm{Xq},{ }^{11}{ }^{12}$ but markers linked to DMD have also been shown to be linked to BMD. ${ }^{613}$ This has been further substantiated by the finding of deletions of the same DNA sequences in

Received for publication 10 July 1986. Accepted for publication 4 August 1986. both DMD and BMD,${ }^{14}{ }^{15}$ and by the fact that two of the girls with $\mathrm{X}$;autosome translocations involving Xp21 have had relatively mild diseases, more compatible with a diagnosis of Becker than Duchenne muscular dystrophy. ${ }^{16} 17$

In order to increase their usefulness in clinical situations, the linkage of polymorphic loci to the disease loci must be studied in pedigrees. We have investigated the linkage of four polymorphic loci defined by probes 99.6 $\left(D X S 41^{18}\right)$, pERT87 $\left(D X S 164^{19}\right), 754\left(D X S 84^{7}\right)$, and $\mathrm{pXJ} 1 \cdot 1^{20}$ to DMD and BMD. Locus DXS84 is centromeric to the disease locus and DXS41 is telomeric, while the precise locations of the others have not yet been defined relative to the disease locus. ${ }^{15}$

\section{Materials and methods}

\section{SUBJECTS}

We have studied five BMD families and 20 DMD families taken from the total clinic population described by Hodgson et al. ${ }^{21}$ Each kindred contained at least two affected males. Subjects used in linkage analysis were unaffected and affected males and females who were obligate carriers. Information is available on a total of 35 meiotic events in three 
TABLE 1 Information on the DNA probes used in this study.

\begin{tabular}{|c|c|c|c|c|c|}
\hline Probe & Locus & $\begin{array}{l}\text { Restriction } \\
\text { enzyme }\end{array}$ & $\begin{array}{l}\text { Band sizes } \\
(k b)\end{array}$ & $\begin{array}{l}\text { Heterozygosity } \\
\text { frequency (\%) }\end{array}$ & $\begin{array}{l}\text { Origin of } \\
\text { probe }\end{array}$ \\
\hline 99.6 & $D X S 41$ & PstI & $22+13$ & 41 & Kunkel $^{1824}$ \\
\hline pERT87.15 & DXS164 & $X m n I$ & $2 \cdot 8+(1 \cdot 6+1 \cdot 2)$ & $41 \cdot 5$ & Kunkel $^{15}$ \\
\hline pERT $87 \cdot 15$ & DXS164 & TaqI & $3 \cdot 3+3 \cdot 1$ & 37 & Kunkel ${ }^{15}$ \\
\hline pERT 87.8 & DXS164 & Bst XI & $4 \cdot 4+2 \cdot 2$ & 41 & Kunkel ${ }^{15}$ \\
\hline pERT87.1 & DXS164 & $X m n I$ & $8 \cdot 7+7 \cdot 5$ & 36 & Kunkel $^{15}$ \\
\hline $\mathrm{pXJ} 1 \cdot 1$ & & Taql & $3 \cdot 8+3 \cdot 1$ & 30 & Worton ${ }^{20}$ \\
\hline 754 & $D X S 84$ & PstI & $12+9$ & 50 & Pearson $^{7}$ \\
\hline
\end{tabular}

generation families and 30 meiotic events in two generation families (appendix). Serum CK results on carrier females were usually available, but were not used in the calculation of linkage results.

DNA PREPARATION

DNA was extracted from whole blood using the method described by Kunkel et al. ${ }^{22}$ DNA $(10 \mu \mathrm{g})$ was digested with the appropriate restriction enzymes for the various probes (table 1) and the resulting fragments were separated on $0 \cdot 8 \%$ agarose gels by electrophoresis overnight at constant voltage (45 to $55 \mathrm{~V})$. The separated DNA was transferred to Zetaprobe membranes (Biorad) by Southern blotting. $^{23}$

\section{ORIGIN OF PROBES}

Probe 754 was selected from a flow sorted X chromosome library as a single copy sequence. It has been localised proximal to the DMD locus using rodent-human cell hybrids. ${ }^{7}$ Probe 99.6 was also isolated from a flow sorted $\mathrm{X}$ chromosome specific library, ${ }^{1824}$ and maps distal to the DMD locus. The pERT probes were selected from a library highly enriched for human DNA from Xp21, which had been constructed using DNA isolated from a male patient who had a cytogenetically visible deletion and three $\mathrm{X}$ linked disorders. ${ }^{19} \mathrm{pXJ} 1 \cdot 1$ is the cloned junction fragment of the $(\mathrm{X} ; 21)$ translocation causing muscular dystrophy in a girl with the karyotype $46, \mathrm{X}, \mathrm{t}(\mathrm{X} ; 21)(\mathrm{p} 21 \cdot 1 ; \mathrm{p} 12)$ or $(\mathrm{p} 21 \cdot 2 ; \mathrm{p} 12) .{ }^{17} 20$

\section{HY B R I D IS ATION}

Prehybridisation was carried out using salmon sperm DNA $(100 \mu \mathrm{g} / \mathrm{ml})$ at $65^{\circ} \mathrm{C}$. Hybridisation was also carried out at $65^{\circ} \mathrm{C}$ in $3 \times \mathrm{SSC}, 0 \cdot 1 \%$ SDS, 100 $\mu \mathrm{g} / \mathrm{ml}$ salmon sperm DNA, and $2 \times$ Denhardt's. Probes 754 and 99.6 were labelled by nick translation using Amersham nick-kit; pERT probes and pXJ1.1 were labelled using a hexanucleotide primed reaction. ${ }^{25}$ Hybridisation was for 48 hours and filters were washed to $1 \times \mathrm{SSC}, 0 \cdot 1 \%$ SDS or $0.2 \times \mathrm{SSC}$, $0.1 \%$ SDS, depending on the properties of the probe.

\section{LINKAGE ANALYSIS}

Linkage analysis was carried out using two point analysis on the computer programme LIPED (IBM

TABLE 2 Lod scores for Duchenne muscular dystrophy and marker loci defined by the probes used.

\begin{tabular}{|c|c|c|c|c|c|c|c|}
\hline$\theta$ & $\begin{array}{l}99 \cdot 6 \\
(n=10)\end{array}$ & $\begin{array}{l}p E R T 87 \cdot 15 \\
(n=11)\end{array}$ & $\begin{array}{l}p E R T 87 \cdot 8 \\
(n=7)\end{array}$ & $\begin{array}{l}p E R T 87 \cdot 1 \\
(n=8)\end{array}$ & $\begin{array}{l}\text { Combined } \\
p E R T \\
(n=16)\end{array}$ & $\begin{array}{l}p X J 1 \cdot 1 \\
(n=8)\end{array}$ & $\begin{array}{l}754 \\
(n=14)\end{array}$ \\
\hline 0.00 & $-\infty$ & $4 \cdot 708$ & $-\infty$ & $-\propto$ & $-\infty$ & 3.613 & $-\infty$ \\
\hline 0.01 & 1.892 & 4.590 & 1.024 & $2 \cdot 122$ & $4 \cdot 783$ & 3.530 & -0.670 \\
\hline 0.02 & $2 \cdot 117$ & $4 \cdot 473$ & $1 \cdot 266$ & $2 \cdot 336$ & 4.928 & 3.446 & 0.405 \\
\hline 0.03 & $2 \cdot 217$ & $4 \cdot 356$ & $1 \cdot 383$ & $2 \cdot 428$ & 4.952 & $3 \cdot 364$ & 0.983 \\
\hline 0.04 & $2 \cdot 265$ & $4 \cdot 329$ & 1.449 & 2.467 & 5.011 & $3 \cdot 280$ & $1 \cdot 352$ \\
\hline 0.06 & $2 \cdot 284$ & $4 \cdot 601$ & $1 \cdot 505$ & $2 \cdot 468$ & $4 \cdot 784$ & $3 \cdot 110$ & 1.794 \\
\hline 0.07 & $\overline{2 \cdot 271}$ & 3.882 & 1.512 & $2 \cdot 447$ & 4.695 & 3.025 & 1.930 \\
\hline 0.08 & $2 \cdot 251$ & 3.765 & 1.510 & $2 \cdot 419$ & $4 \cdot 597$ & 2.941 & 2.030 \\
\hline 0.09 & $2 \cdot 223$ & 3.645 & $1 \cdot 501$ & $2 \cdot 384$ & 4.440 & $2 \cdot 856$ & $2 \cdot 102$ \\
\hline $0 \cdot 10$ & $2 \cdot 187$ & $3 \cdot 528$ & 1.487 & $2 \cdot 342$ & $4 \cdot 383$ & $2 \cdot 771$ & $2 \cdot 152$ \\
\hline $0 \cdot 11$ & $2 \cdot 147$ & 3.410 & 1.467 & 2.295 & $4 \cdot 268$ & 2.686 & $2 \cdot 183$ \\
\hline 0.12 & $2 \cdot 105$ & $3 \cdot 290$ & 1.444 & $2 \cdot 244$ & $4 \cdot 148$ & $2 \cdot 600$ & $2 \cdot 199$ \\
\hline $0 \cdot 13$ & $2 \cdot 058$ & $3 \cdot 171$ & 1.419 & $2 \cdot 190$ & $4 \cdot 024$ & $2 \cdot 514$ & $2 \cdot 203$ \\
\hline 0.14 & $2 \cdot 008$ & 3.054 & $1 \cdot 390$ & $2 \cdot 137$ & 3.901 & $2 \cdot 430$ & $\frac{2007}{2 \cdot 197}$ \\
\hline $0 \cdot 17$ & 1.844 & 2.701 & 1.292 & 1.955 & $3 \cdot 517$ & $2 \cdot 172$ & $2 \cdot 125$ \\
\hline
\end{tabular}

$\mathrm{n}=$ number of informative Duchenne families.

Maximum lod scores are underlined. 
PC/XT 1985 version). ${ }^{26}$ Lod scores were calculated at appropriate recombination fraction intervals. Pedigrees were checked manually for the number of recombinant events between the disease loci and the loci DXS41, DXS164, DXS84, and the locus defined by DNA probe $\mathrm{pXJ} 1 \cdot 1$.

\section{Results}

Five BMD and 20 DMD kindreds were analysed for linkage to each of the probe loci. The genotypes of informative subjects used in the linkage analysis are shown on the pedigrees in the appendix. The lod scores obtained at 0.01 intervals of the recombination fraction $\theta$ for linkage between the four polymorphic loci and the disease loci are shown in table 2 for DMD, table 3 for BMD, and table 4 for the combined DMD and BMD families (the maximum lod scores are also shown in these tables). We have presented the data for the loci defined for the three pERT87 probes separately and have also presented combined data for the DXS164 locus.

\section{Discussion}

The data presented confirm genetic linkage between

TABLE 3 Lod scores for Becker muscular dystrophy and marker loci defined by the probes used.

\begin{tabular}{|c|c|c|c|c|c|c|}
\hline$\theta$ & $\begin{array}{l}99 \cdot 6 \\
(n=3)\end{array}$ & $\begin{array}{l}p E R T 87 \cdot 15 \\
(n=4)\end{array}$ & $\begin{array}{l}p E R T 87 \cdot 1 \\
(n=2)\end{array}$ & $\begin{array}{l}\text { Combined } \\
p E R T \\
(n=5)\end{array}$ & $\begin{array}{l}p X J 1 \cdot 1 \\
(n=2)\end{array}$ & $\begin{array}{l}754 \\
(n=2)\end{array}$ \\
\hline 0.00 & $-\infty$ & $2 \cdot 364$ & 0.903 & 2.966 & 1.505 & 1.505 \\
\hline 0.01 & -0.053 & $\overline{2 \cdot 317}$ & $\overline{0 \cdot 881}$ & $\overline{2.901}$ & $\overline{1.475}$ & $\overline{1.475}$ \\
\hline 0.02 & $0 \cdot 212$ & $2 \cdot 268$ & 0.860 & $2 \cdot 836$ & 1.444 & 1.444 \\
\hline 0.03 & 0.352 & $2 \cdot 219$ & 0.837 & $2 \cdot 768$ & 1.412 & 1.412 \\
\hline 0.04 & 0.441 & $2 \cdot 169$ & $0 \cdot 815$ & $2 \cdot 701$ & $1 \cdot 381$ & $1 \cdot 381$ \\
\hline 0.06 & 0.545 & $2 \cdot 070$ & 0.771 & $2 \cdot 567$ & $1 \cdot 318$ & $1 \cdot 318$ \\
\hline 0.07 & 0.575 & $2 \cdot 019$ & 0.749 & $2 \cdot 498$ & $1 \cdot 285$ & $1 \cdot 285$ \\
\hline 0.08 & 0.595 & 1.967 & 0.726 & $2 \cdot 428$ & $1 \cdot 252$ & $1 \cdot 252$ \\
\hline 0.09 & 0.608 & 1.915 & 0.703 & $2 \cdot 358$ & $1 \cdot 219$ & $1 \cdot 219$ \\
\hline $0 \cdot 10$ & 0.616 & 1.862 & 0.680 & $2 \cdot 287$ & $1 \cdot 185$ & $1 \cdot 185$ \\
\hline $0 \cdot 11$ & 0.620 & 1.809 & 0.658 & $2 \cdot 217$ & $1 \cdot 152$ & $1 \cdot 152$ \\
\hline $0 \cdot 12$ & $\overline{0.618}$ & 1.757 & 0.635 & $2 \cdot 146$ & $1 \cdot 118$ & $1 \cdot 118$ \\
\hline $0 \cdot 13$ & 0.613 & 1.703 & 0.612 & $2 \cdot 074$ & 1.083 & 1.083 \\
\hline 0.14 & 0.607 & $1 \cdot 648$ & 0.588 & $2 \cdot 000$ & $1 \cdot 048$ & 1.048 \\
\hline $0 \cdot 17$ & 0.571 & 1.483 & 0.520 & 1.756 & 0.943 & 0.943 \\
\hline
\end{tabular}

$\mathrm{n}=$ numbers of informative Duchenne families.

Maximum lod scores are underlined.

TABLE 4 Lod scores for Duchenne and Becker muscular dystrophy (combined) defined by the probes used.

\begin{tabular}{|c|c|c|c|c|c|c|c|}
\hline$\theta$ & $\begin{array}{l}99 \cdot 6 \\
(n=13)\end{array}$ & $\begin{array}{l}p E R T 87 \cdot 15 \\
(n=15)\end{array}$ & $\begin{array}{l}p E R T 87 \cdot 8 \\
(n=7)\end{array}$ & $\begin{array}{l}p E R T 87 \cdot 1 \\
(n=10)\end{array}$ & $\begin{array}{l}\text { Combined } \\
p E R T \\
(n=22)\end{array}$ & $\begin{array}{l}p X J 1 \cdot 1 \\
(n=10)\end{array}$ & $\begin{array}{l}754 \\
(n=16)\end{array}$ \\
\hline 0.00 & $-\infty$ & 7.072 & $-\infty$ & $-\infty$ & $-\infty$ & $\underline{5 \cdot 118}$ & $-\infty$ \\
\hline 0.01 & 1.839 & $\overline{6.907}$ & 1.024 & 3.003 & 8.585 & $\overline{5.005}$ & 0.805 \\
\hline 0.02 & $2 \cdot 329$ & $6 \cdot 741$ & $1 \cdot 266$ & $3 \cdot 196$ & 8.634 & $4 \cdot 890$ & 1.849 \\
\hline 0.03 & $2 \cdot 569$ & 6.575 & $1 \cdot 383$ & $3 \cdot 265$ & $\overline{8.560}$ & 4.776 & $2 \cdot 395$ \\
\hline 0.04 & $2 \cdot 706$ & $6 \cdot 498$ & 1.449 & $3 \cdot 282$ & 8.521 & $4 \cdot 661$ & 2.733 \\
\hline 0.06 & $2 \cdot 829$ & 6.071 & 1.505 & $3 \cdot 239$ & 8.095 & 4.428 & $3 \cdot 112$ \\
\hline 0.07 & $2 \cdot 846$ & 5.901 & $1 \cdot 512$ & $3 \cdot 196$ & 7.910 & $4 \cdot 310$ & $3 \cdot 215$ \\
\hline 0.08 & $\overline{2 \cdot 846}$ & $5 \cdot 732$ & $\overline{1 \cdot 510}$ & $3 \cdot 145$ & $7 \cdot 711$ & $4 \cdot 193$ & 3.282 \\
\hline 0.09 & $\overline{2 \cdot 831}$ & $5 \cdot 560$ & $1 \cdot 510$ & 3.087 & $7 \cdot 453$ & $4 \cdot 075$ & $3 \cdot 321$ \\
\hline $0 \cdot 10$ & $2 \cdot 803$ & $5 \cdot 390$ & 1.487 & 3.022 & $7 \cdot 294$ & 3.956 & 3.337 \\
\hline $0 \cdot 11$ & $2 \cdot 767$ & $5 \cdot 219$ & 1.467 & 2.953 & 7.079 & $3 \cdot 838$ & $\overline{3 \cdot 335}$ \\
\hline $0 \cdot 12$ & $2 \cdot 723$ & 5.047 & 1.444 & 2.879 & $6 \cdot 857$ & 3.718 & $3 \cdot 317$ \\
\hline 0.13 & 2.671 & 4.874 & 1.419 & $2 \cdot 802$ & 6.631 & 3.597 & $3 \cdot 286$ \\
\hline 0.14 & $2 \cdot 615$ & $4 \cdot 702$ & $1 \cdot 390$ & 2.725 & 6.403 & 3.478 & $3 \cdot 245$ \\
\hline 0.17 & $2 \cdot 415$ & $4 \cdot 184$ & $1 \cdot 292$ & $2 \cdot 475$ & $5 \cdot 686$ & $3 \cdot 115$ & 3.068 \\
\hline
\end{tabular}

$\mathrm{n}=$ number of informative families. 
DMD and the four polymorphic loci and also between BMD and the polymorphic loci described. This is consistent with previous studies showing similar linkage relationships of BMD and DMD. ${ }^{6}{ }^{13}$ We believe that the combined information from translocations, deletions, and linkage studies now strongly supports the hypothesis that DMD and BMD are allelic and justifies pooling the linkage data for clinical predictive testing. By using hybrid cell lines, translocations, and linkage data, the loci DXS41 and DXS84 have been located relative to the disease locus in the following order ${ }^{8}:$ telomere $\rightarrow$ $D X S 41 \rightarrow B M D / D M D \rightarrow D X S 84 \rightarrow$ centromere.

We have combined our results for these two loci with those that have previously been published (tables 5 and 6). This shows linkage between $B M D / D M D$ and locus $D X S 41$, with a maximum lod score of 11.642 at a recombination fraction of $0 \cdot 15$. The maximum lod score of linkage between locus $D X S 84$ and $B M D / D M D$ is 15.84 at a recombination fraction of $0 \cdot 15$. The lod scores from each study are comparable.

The other two polymorphic loci that we have studied, DXS164 and the locus defined by probe
$\mathrm{pXJ} 1 \cdot 1$, have been shown to be deleted from some boys suffering from DMD and BMD. Approximately $7 \%$ of DMD patients have a deletion of the DNA sequences of the pERT 87 locus. ${ }^{15}$ The screening of affected boys with these two DNA probes has led to the following tentative relationship ${ }^{15}$ : telomere $\rightarrow D X S 41 \rightarrow D X S 164 \rightarrow \mathrm{pXJ} 1 \cdot 1 \rightarrow D X S 84 \rightarrow$ centromere.

The precise location of the closer DNA sequences relative to the disease locus is not known. Hybridisation of these cloned DNA sequences to somatic cell hybrids containing the translocated chromosomes from female patients suffering from BMD and DMD show that the breakpoints of the $\mathrm{X}$ chromosome, although cytologically visible at Xp21, do vary, and that some are distal to $\mathrm{pXJ} 1 \cdot 1$ and pERT 87 , while others are proximal. ${ }^{27}$ The breakpoints all lead to manifestations of the disease, suggesting that both loci are within the region functionally related to muscular dystrophy.

Although locus DXS164 shows deletions in affected boys, it has been reported to show recombination at about $5 \% .{ }^{15}$ We have found one crossover between DXS164 and the disease locus (family

TABLE 5 Lod scores for DXS84(754) versus (a) BMD, (b) DMD, and (c) BMD + DMD.

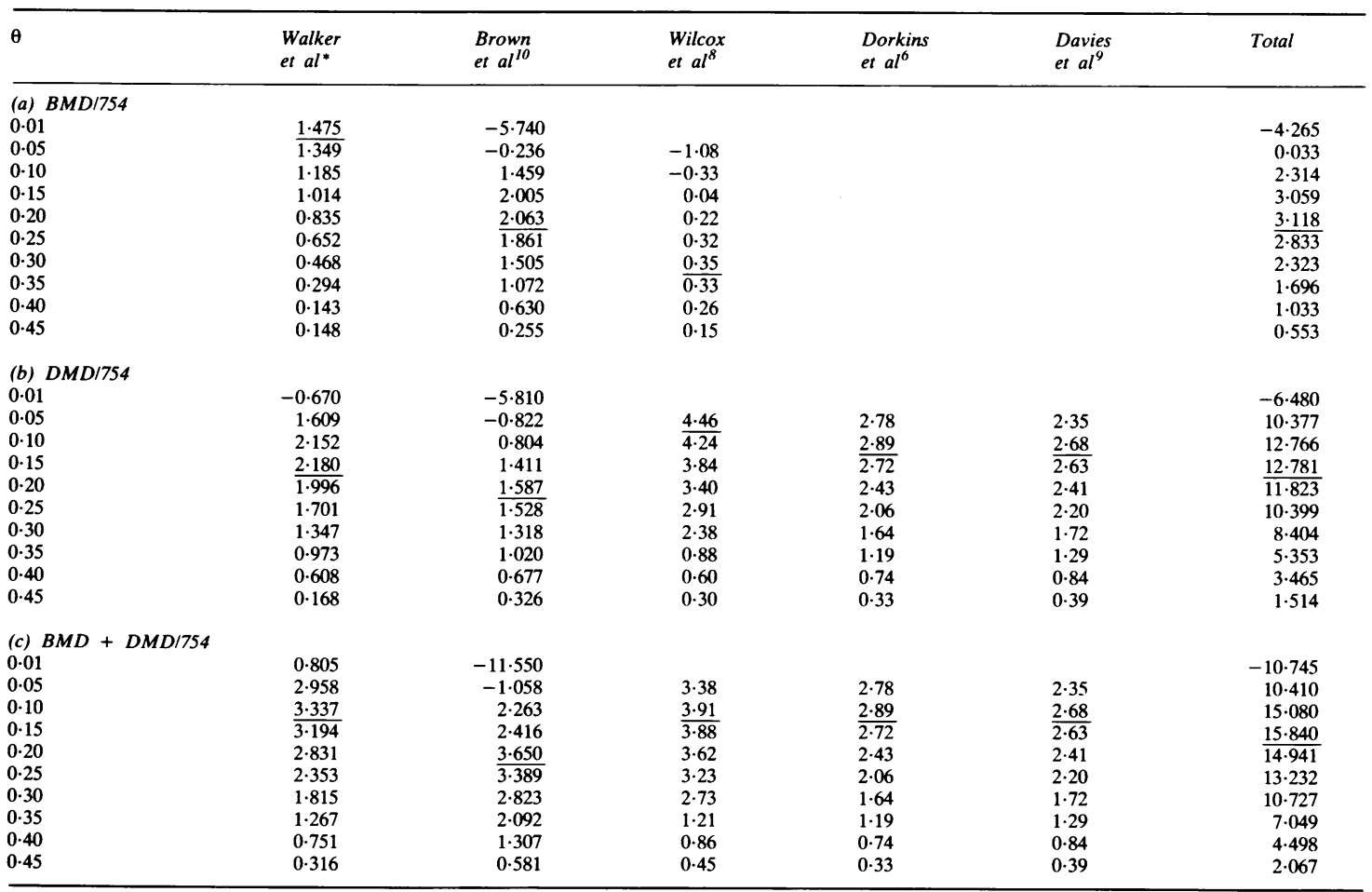

Maximum lod scores are underlined.

*This study. 
TABLE 6 Lod scores for DXS41 (99.6) versus (a) BMD, (b) $D M D$, and (c) $B M D+D M D$.

\begin{tabular}{|c|c|c|c|c|}
\hline$\theta$ & $\begin{array}{l}\text { Walker } \\
\text { et al* }\end{array}$ & $\begin{array}{l}\text { Brown } \\
\text { et al }\end{array}$ & $\begin{array}{l}\text { Wilcox } \\
\text { et al }\end{array}$ & Total \\
\hline \multicolumn{5}{|c|}{ (a) $B M D / 99.6$} \\
\hline 0.01 & -0.053 & $-1 \cdot 394$ & & -1.447 \\
\hline 0.05 & 0.502 & $2 \cdot 198$ & 0.94 & $3 \cdot 640$ \\
\hline $0 \cdot 10$ & 0.616 & $3 \cdot 194$ & $0 \cdot 85$ & $4 \cdot 660$ \\
\hline $0 \cdot 15$ & 0.597 & 3.392 & 0.76 & 4.749 \\
\hline 0.20 & 0.520 & $3 \cdot 234$ & 0.66 & $4 \cdot 414$ \\
\hline 0.25 & 0.411 & $2 \cdot 871$ & 0.56 & $3 \cdot 842$ \\
\hline 0.30 & 0.287 & 2.369 & 0.46 & $3 \cdot 116$ \\
\hline 0.35 & $0 \cdot 165$ & 1.718 & 0.35 & $2 \cdot 223$ \\
\hline 0.40 & 0.061 & $1 \cdot 154$ & 0.24 & 1.455 \\
\hline 0.45 & 0.001 & 0.546 & 0.12 & 0.667 \\
\hline \multicolumn{5}{|c|}{ (b) $D M D / 99.6$} \\
\hline 0.01 & 1.892 & -2.945 & & $-1 \cdot 053$ \\
\hline 0.05 & $2 \cdot 283$ & 0.679 & $3 \cdot 21$ & $6 \cdot 172$ \\
\hline $0 \cdot 10$ & $\overline{2 \cdot 187}$ & 1.752 & $\overline{3 \cdot 04}$ & 6.979 \\
\hline $0 \cdot 15$ & 1.956 & 2.057 & $2 \cdot 88$ & $6 \cdot 893$ \\
\hline $0 \cdot 20$ & 1.666 & $2 \cdot 049$ & 2.46 & $6 \cdot 175$ \\
\hline 0.25 & $1 \cdot 349$ & 1.860 & $2 \cdot 08$ & $5 \cdot 289$ \\
\hline 0.30 & 1.024 & 1.568 & 1.68 & $4 \cdot 272$ \\
\hline 0.35 & 0.710 & $1 \cdot 211$ & $1 \cdot 27$ & $3 \cdot 191$ \\
\hline 0.40 & 0.424 & 0.823 & 0.85 & $2 \cdot 097$ \\
\hline 0.45 & $0 \cdot 182$ & $0 \cdot 414$ & 0.42 & 1.016 \\
\hline \multicolumn{5}{|c|}{ (c) $B M D+D M D / 99.6$} \\
\hline 0.01 & 1.839 & $-4 \cdot 339$ & & $-2 \cdot 500$ \\
\hline 0.05 & $2 \cdot 785$ & 2.877 & $4 \cdot 15$ & $9 \cdot 812$ \\
\hline $0 \cdot 10$ & $2 \cdot 803$ & 4.946 & $3 \cdot 89$ & 11.639 \\
\hline $0 \cdot 15$ & $\frac{2.000}{2 \cdot 553}$ & 5.449 & 3.64 & $11 \cdot 642$ \\
\hline $0 \cdot 20$ & $2 \cdot 186$ & $5 \cdot 283$ & $3 \cdot 12$ & $10 \cdot 589$ \\
\hline 0.25 & 1.760 & $4 \cdot 731$ & $2 \cdot 64$ & $9 \cdot 131$ \\
\hline 0.30 & $1 \cdot 311$ & 3.937 & $2 \cdot 14$ & $7 \cdot 388$ \\
\hline 0.35 & 0.875 & 2.992 & 1.62 & 5.487 \\
\hline 0.40 & 0.485 & 1.997 & 1.09 & $3 \cdot 572$ \\
\hline 0.45 & $0 \cdot 183$ & 0.960 & 0.54 & 1.683 \\
\hline
\end{tabular}

Maximum lod scores are underlined.

*This study.

D6 in the appendix). Our data show a maximum lod score of 8.634 at $\theta=0.02$, supporting the use of a recombination fraction of about $5 \%$ for genetic counselling purposes. These two loci are, therefore, closer than any of the previously published linked loci, and so will give a more accurate figure for carrier risks and in prenatal diagnosis. The heterozygote frequencies of the pERT probes indicate that $95 \%$ of women will be heterozygous for at least one polymorphic site.

In families where the affected boy shows a deletion of a pERT or $\mathrm{pXJ} 1 \cdot 1$ DNA sequence, the appropriate probe can often be used to give even more accurate counselling, particularly where prenatal diagnosis is required, since the disease causing mutation is effectively being probed directly.

Prenatal diagnosis is best undertaken when the expectant mother is heterozygous for DNA probes which define loci flanking the disease locus. ${ }^{28}$ The risk of error then becomes the risk of a double recombinational event, which is very low. Unfortunately, the pERT probes and pXJ1.1 cannot currently be used as flanking markers, in conjunction with other probes, as their precise location relative to the disease locus is not known and may, indeed, vary from family to family. It is, therefore, important to test women with more loosely linked DNA probes as well, to try and establish heterozygous flanking markers. For calculating carrier risks, the pedigree and $\mathrm{CK}$ data must also be taken into account. ${ }^{29}$

It is important that the linkage between the disease locus and loci newly defined by DNA probes is constantly reviewed, so that up to date figures can be used in calculating carrier risks and enabling prenatal diagnosis to be carried out more accurately in families at risk for Duchenne and Becker muscular dystrophy.

We gratefully acknowledge the financial support of the Muscular Dystrophy Group of Great Britain and Northern Ireland and of the Generation Trust. We thank especially the many families who have kindly agreed to participate in this study. Many thanks are also due to Elizabeth Manners for her dedication to the project, the immense amount of time spent collating the patient data over the last three years, and the preparation and typing of this manuscript. We are indebted to Dr L Kunkel, Dr R Worton, and Professor P Pearson for the provision of probes, antio to Dr K Davies for her advice and support.

\section{References}

1 Gardner-Medwin D. Clinical features and classification of the muscular dystrophies. Br Med Bull 1980;36:109-15.

2 Zatz M, Vianna-Morgante AM, Campos P, Diament AJ Translocation $(X ; 6)$ in a female with Duchenne muscular dystrophy: implications for the localisation of the DMD locus. $J$ Med Genet 1981;18:442-7.

${ }^{3}$ Emanuel BS, Zackai EH, Tucker S. Further evidence for Xp21 location of Duchenne muscular dystrophy (DMD) locus: X;9 translocation in a female with DMD. J Med Genet 1983;20:4613.

${ }^{4}$ Murray JM, Davies KE, Harper PS, Meredith L, Mueller CR, Williamson R. Linkage relationship of a cloned DNA sequence on the short arm of the X-chromosome to Duchenne muscular dystrophy. Nature 1982;300:69-71.

5 Davies KE, Pearson PL, Harper PS, et al. Linkage analysis of two cloned DNA sequences flanking the Duchenne muscular dystrophy locus on the short arm of the human X-chromosome. Nucleic Acids Res 1983;11:2303-12.

${ }^{6}$ Dorkins H, Junien C, Mandel JL, et al. Segregation analysis of a marker localised Xp21.2 $\rightarrow \mathrm{Xp} 21.3$ in Duchenne and Becker muscular dystrophy families. Hum Genet 1985;71:103-7.

${ }^{7}$ Hofker MH, Wapenaar MC, Goor N, Bakker B, Van Ommen GJB, Pearson PL. Isolation of probes detecting restriction fragment length polymorphisms from $\mathrm{X}$ chromosome specific libraries: potential use for diagnosis of Duchenne muscular dystrophy. Hum Genet 1985;70:148-56.

${ }^{8}$ Wilcox DE, Affara NA, Yates JRW, Ferguson-Smith MA, Pearson PL. Multipoint linkage analysis of the short arm of the human $\mathrm{X}$ chromosome in families with $\mathrm{X}$-linked muscular dystrophy. Hum Genet 1985;70:365-75.

9 Davies KE, Speer A, Herrmann F, et al. Human X chromosome 
markers and Duchenne muscular dystrophy. Nucleic Acids Res 1985;13:3419-26.

${ }^{10}$ Brown CS, Thomas NST, Sarfarazi M, et al. Genetic linkage relationships of seven DNA probes with Duchenne and Becker muscular dystrophy. Hum Genet 1985;71:62-74.

11 Emery AEH, Smith CAB, Sanger R. The linkage relationships of the loci for benign (Becker type) X-borne muscular dystrophy, colour blindness and the Xg blood groups. Ann Hum Genet 1969;32:261-9.

12 Skinner R, Smith C, Emery AEH. Linkage between the loci for benign (Becker-type) X-borne muscular dystrophy and deutan colour blindness. J Med Genet 1974;11:317-20.

${ }^{13}$ Kingston HM, Sarfarazi M, Thomas NST, Harper PS. Localisation of the Becker muscular dystrophy gene on the short arm of the X-chromosome by linkage to cloned DNA sequences. Hum Genet 1984;67:6-17.

${ }^{14}$ Hodgson S, Hart K, Walker A, et al. DNA deletion in boy with Becker muscular dystrophy. Lancet 1986;i:918.

15 Kunkel LM, Hejtmancik JF, Caskey CT, et al. Analysis of deletions in DNA from patients with Becker and Duchenne muscular dystrophy. Nature 1986;322:73-7.

${ }^{16}$ Nielsen LB, Jacobson BB, Nielsen IM, Tabor A. X;autosome translocation in a girl with muscular dystrophy. Clin Genet 1983;23:242A

17 Verellen C, Markovic V, DeMeyer R, Freund M, Laterre C, Worton R. Expression of an $\mathrm{X}$-linked recessive disease in a female due to non-random inactivation of the $\mathrm{X}$ chromosome. Am J Hum Genet 1978;30:97A.

${ }^{18}$ Aldridge J, Kunkel L, Bruns G, et al. A strategy to reveal high frequency RFLPs along the human X chromosome. Am J Hum Genet 1984;36:546-64.

${ }^{19}$ Monaco AP, Bertelson CJ, Middlesworth W, et al. Detection of deletions spanning the Duchenne muscular dystrophy locus using a tightly linked DNA segment. Nature 1985;316:842-5.
20 Ray PN, Belfall B, Duff C. et al. Cloning of the breakpoint of an $\mathrm{X} ; 21$ translocation associated with Duchenne muscular dystrophy. Nature 1985;318:672-5.

21 Hodgson S, Walker A, Cole C, et al. The application of linkage analysis to genetic counselling in families with Duchenne or Becker muscular dystrophy. J Med Genet (in press).

22 Kunkel LM, Smith KD, Boyer SH, et al. Analysis of human Y-chromosome-specific reiterated DNA in chromosome variants. Proc Natl Acad Sci USA 1977;74:1245-9.

${ }^{23}$ Southern EM. Detection of specific sequences among DNA fragments separated by gel electrophoresis. J Mol Biol 1975;98:503-17.

${ }^{24}$ Kunkel LM, Tantravahi U, Eisenhard M, Latt SA. Regional localisation on the human X of DNA sequences cloned from flow sorted chromosomes. Nucleic Acids Res 1982;10:1557-78.

${ }^{25}$ Feinberg AP, Vogelstein B. A technique for radiolabelling DNA restriction endonuclease fragments to high specific activity. Anal Biochem 1983;132:6-13.

${ }^{26} \mathrm{Ott} \mathrm{J}$. Estimation of the recombination fraction in human pedigrees: efficient computation of the likelihood for human linkage studies. Am J Hum Genet 1974;26:588-97.

27 Boyd Y, Buckle VJ. Cytogenetic heterogeneity of translocations associated with Duchenne muscular dystrophy. Clin Genet 1986;29:108-15.

${ }^{28}$ Bakker E, Hofker MH, Goor N, et al. Prenatal diagnosis and carrier detection of Duchenne muscular dystrophy with closely linked RFLPs. Lancet 1985;i:655-8.

29 Williams H, Sarfarazi M, Brown C, Thomas N, Harper PS. The use of flanking markers in prediction for Duchenne muscular dystrophy. Arch Dis Child 1986;61:218-22.

Correspondence and requests for reprints to Mrs A Walker, Paediatric Research Unit, Guy's Hospital Medical School, Guy's Tower, London SE1 9RT. 
APPENDIX Pedigrees with genotypes of families used in this study. Prefix $B$ denotes a Becker family and prefix $D a$ Duchenne family. Key to pedigrees: $A=99 \cdot 6 . B=p E R T 87 \cdot 15 / X m n I$. C $=p E R T 87 \cdot 8 / B s t X I . D=p E R T 87 \cdot 1 / X m n I$. $E=p X J 1 \cdot 1 . F=754 . G=p E R T 87 \cdot 15 /$ TaqI. $1=$ larger allele size. $2=$ smaller allele size.
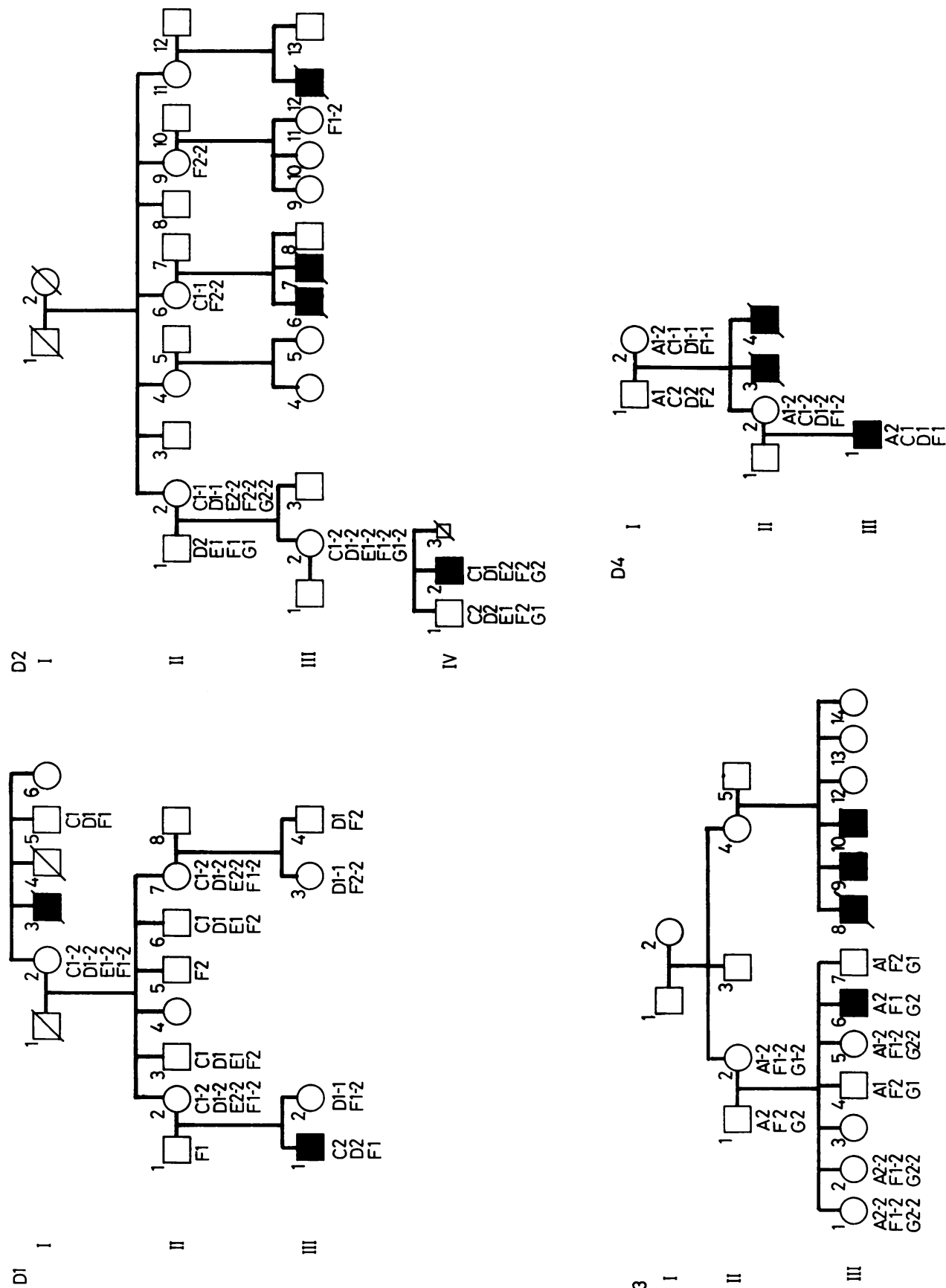

๓ 

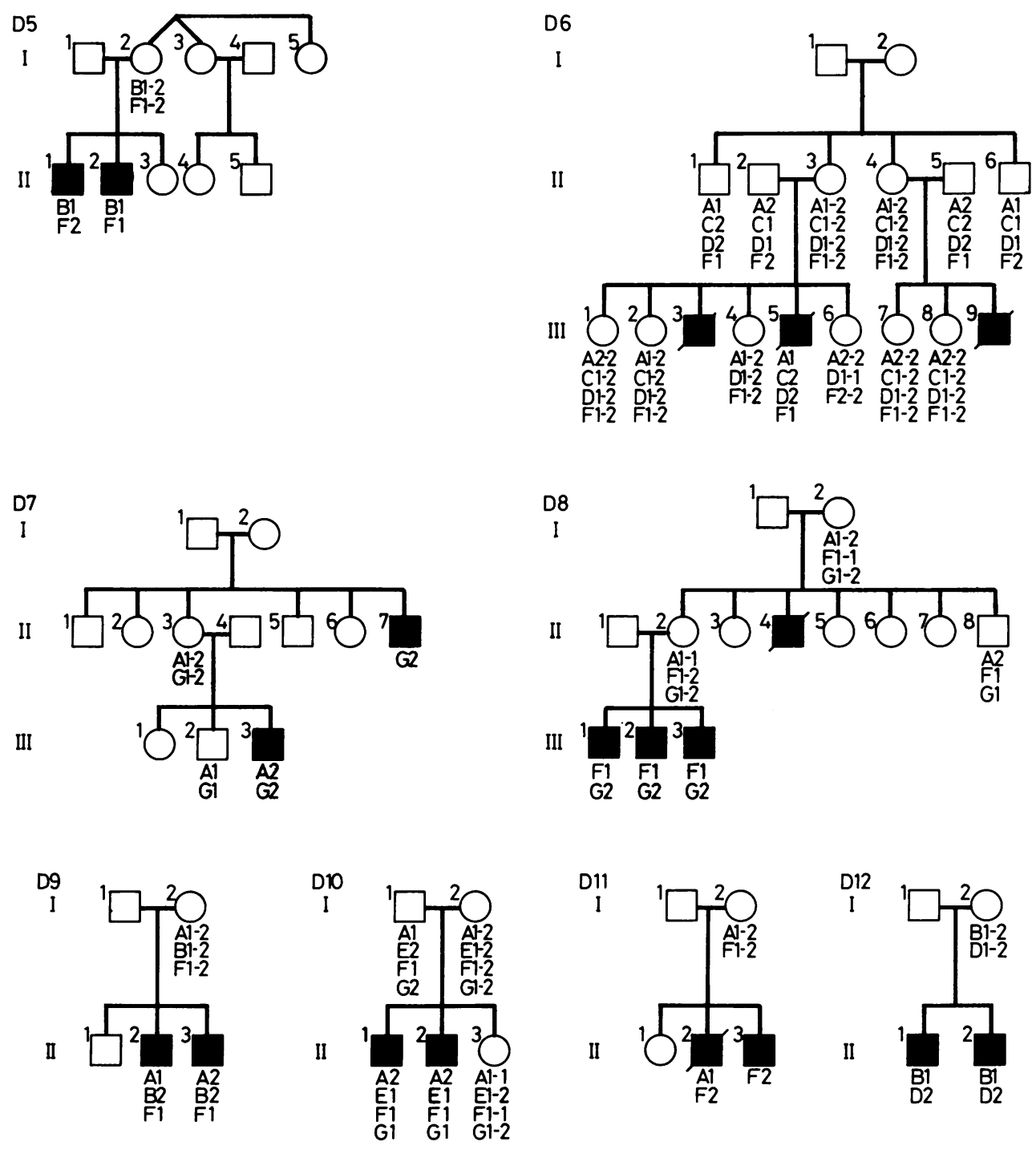


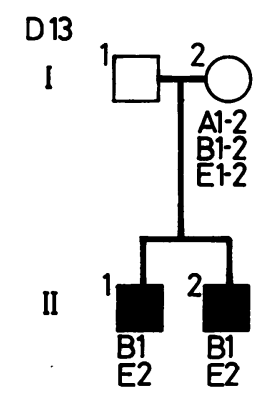

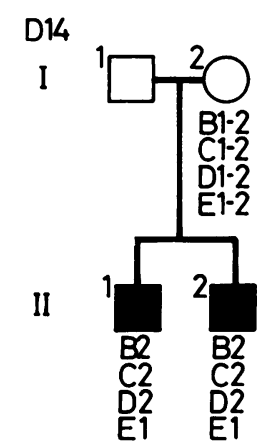

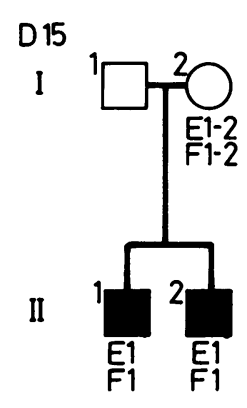

Alison Walker et al

ه

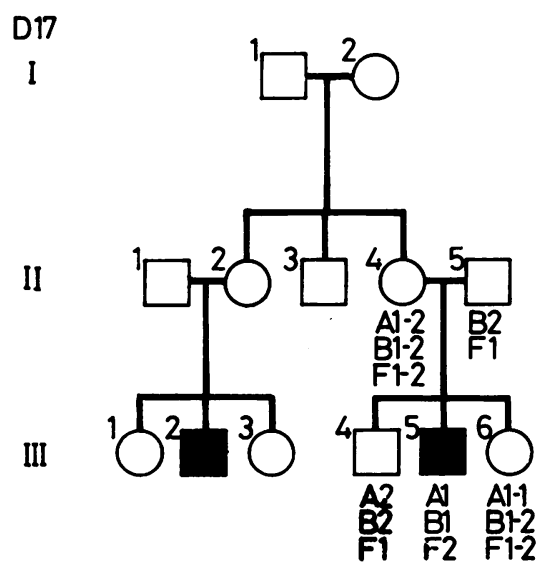

D18
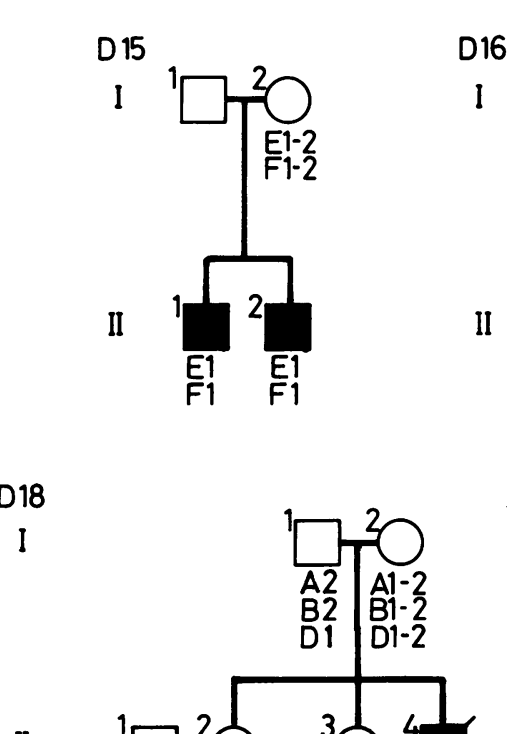

II

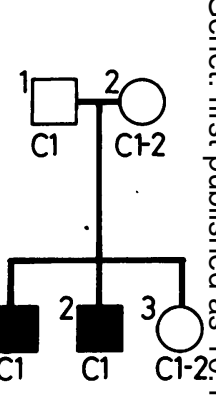

$\overrightarrow{\vec{\omega}}$
o
$\overline{\bar{\Xi}}$
0

II

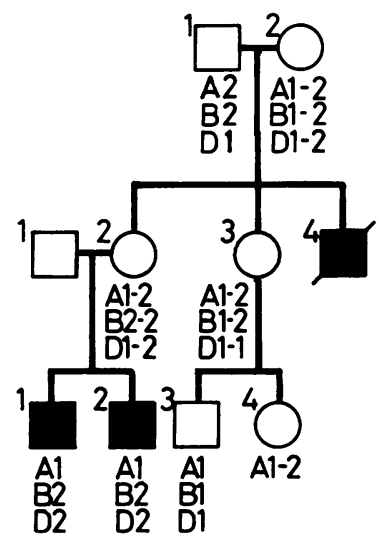

III

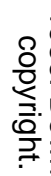

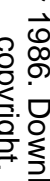

D19

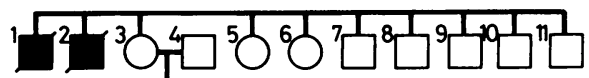

II

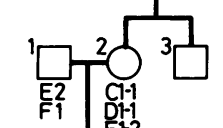

응

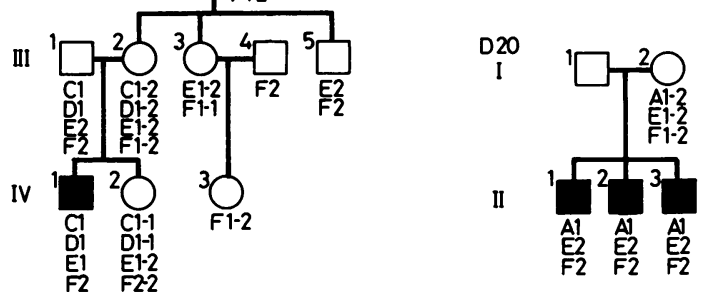



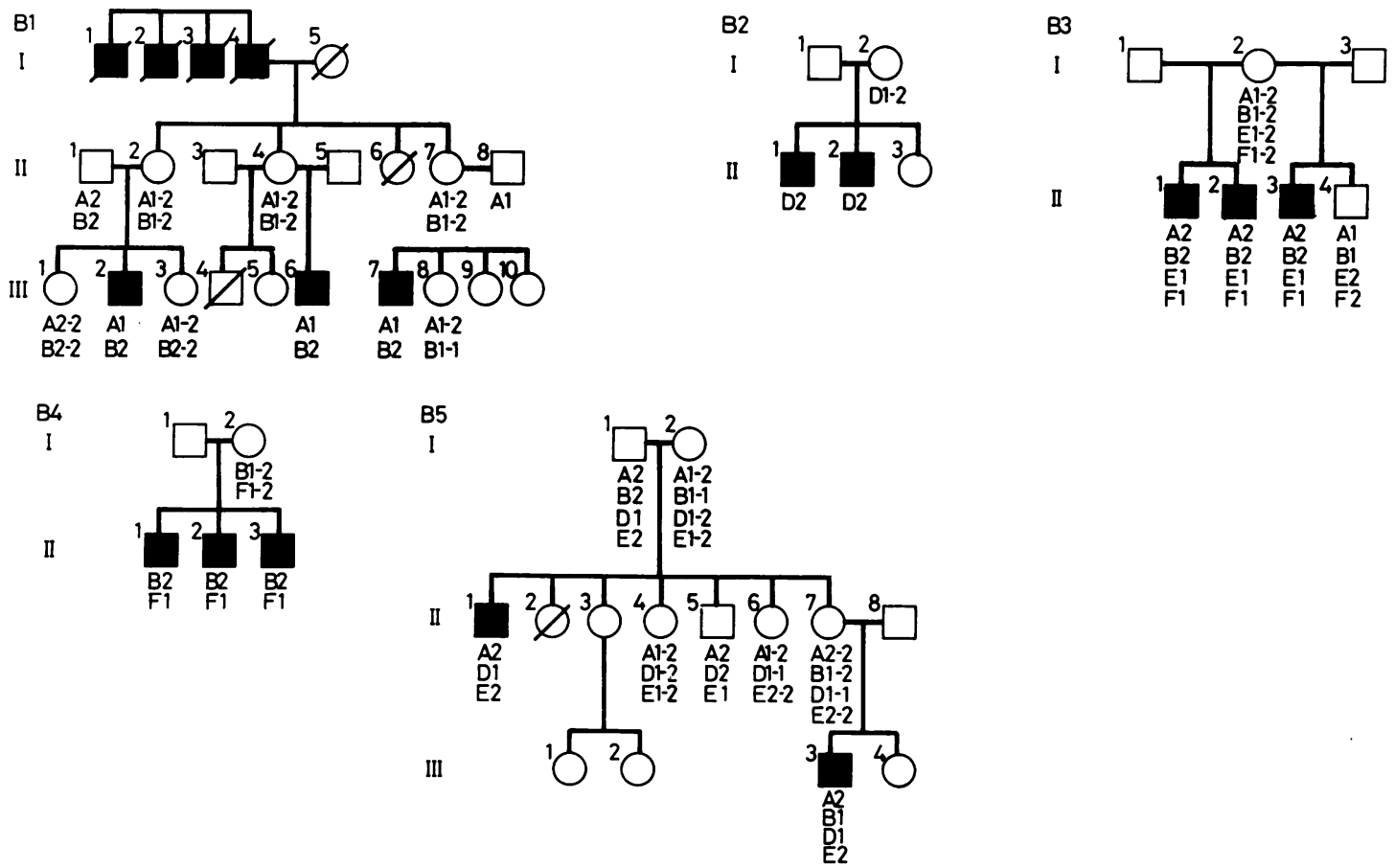